\title{
KEPERCAYAAN MASYARAKAT TERHADAP INFORMASI TRADISIONAL DAN MODERN PADA PERISTIWA BENCANA ALAM
}

\author{
Damayanti Wardyaningrum
}

\author{
Program Studi Ilmu Komunikasi FISIP Universitas Al Azhar Indonesia \\ Jl. Sisingamangaraja Kebayoran Baru, Kompleks Masjid Agung Al Azhar Jakarta Selatan \\ Telp (021) 7244456 \\ Email : damayanti@uai.ac.id
}

\begin{abstract}
The purpose of the research is to identify the local people believe in current information or traditional information of the natural disaster of Merapi mountain in Central Java as one of the mostactive volcanoes in the world. Concept use is information and natural disaster. The research uses post-positivist paradigm with the survey, interview, and observation for data gathering regarding the big eruption in 2010. The results show more than half of local people believe in traditional information than modern information regarding the natural disaster. The differences of local people believe are base on the level of education, age and the role in public. Local citizen believes to traditional information mostly are old people their education background from the elementary level, and has no role in public. On the other hand for the local citizen that believe to modern information are young people, from middle-level education and some of them has a role in public. The perception of traditional information occurs since the old people have some experiences of last volcanic eruption, and more listen to the people they closed and less of literation regarding disaster mitigation. The differences of belief to both traditional and modern information are not statistically significant is an opportunity for integrating traditional and modern information for disaster risk reduction. This research contributes to give insight of the difference of traditional and modern information on disaster events.
\end{abstract}

Keywords: traditional information, modern information, natural disaster

\begin{abstract}
Abstrak
Penilitian ini bertujuan untuk mengidentifikasi kepercayaan warga lokal terhadap informasi tradisional dan informasi modern tentang peristiwa bencana erupsi gunung Merapi di Jawa Tengah sebagai salah satu gunung berapi teraktif didunia. Konsep yang digunakan adalah teori informasi dan bencana alam dengan paradigma penelitian postpositivist. Pengumpulan data melalui survey didukung dengan wawancara serta pengamatan lapangan. Hasil penelitian menemukan lebih banyak warga lokal yang percaya pada informasi tradisional daripada informasi modern tentang bencana. Perbedaan kepercayaan terhadap informasi ditinjau dari tingkat usia, tingkat pendidikan dan perbedaan peran warga di masyarakat. Umumnya warga yang memercayai informasi tradisional berusia tua, berpendidikan sekolah dasar dan tidak memiliki peran di masyarakat. Sementara warga yang memercayai informasi modern berusia muda, berpendidikan menengah dan memiliki peran dimasyarakat. Kecenderungan kepercayaan terhadap informasi tradisional karena warga lokal lebih percaya informasi yang berasal dari orang-orang yang dekat dan masih kurangnya informasi tentang mitigasi bencana. Tidak ditemukan konflik terkait perbedaan kepercayaan warga namun perbedaan jumlah warga yang tidak signifikan merupakan peluang untuk mengintegrasikan informasi tradisional dan informasi modern untuk literasi tentang pengurangan risiko bencana. Kontribusi penelitian ini adalah menambah wawasan mengenai perbedaan informasi tradisional dan modern pada peristiwa bencana.
\end{abstract}

Kata kunci : Informasi tradisional, informasi modern, bencana alam. 


\section{Pendahuluan}

Pendekatan antropologi menerangkan bahwa bencana dapat membangun pemaknaan sosial tentang suatu peristiwa untuk memberikan dasar membangun disposisi yang lebih kuat dan matang pada perjalanan siklus sosial selanjutnya. Abdullah dalam Effendi (2007: 77) membagi empat kategori pemaknaan sosial tentang bencana. Pertama, bencana bukan suatu peristiwa yang tibatiba dan tak terelakkan, tetapi menjadi bagian yang integral dari kehidupan rutin dan normal. Kedua, tidak semua fenomena alam dapat dan harus menjadi bencana, karena lahirnya suatu bencana tergantung pada status kerentanan individu, kelompok, lingkungan dan institusi. Ketiga, bencana sebagai ujian bagiketerbatasan dan daya tahan manusia. Keempat, bencana merupakan peluang bagi perbaikan dan penataan hidup secara mendasar.

Peningkatan jumlah penduduk yang dapat meningkatkan kerentanan saat terjadi peritiwa alam, maka diperlukan informasi yang memadai agar masyarakat dapat mengelola risiko yang mungkin timbul dari setiap peristiwa alam agar tidak menjadi bencana.

Undang-Undang Republik Indonesia Nomor 24 Tahun 2007 tentang Penanggulangan Bencana tertera beberapa pasal terkait tentang pentingnya informasi. Pasal 21 tertulis bahwa Badan Penanggulangan Bencana Daerah mempunyai tugas menyusun, menetapkan, dan menginformasikan peta rawan bencana. Pasal lainnya disebutkan bahwa setiap orang berhak untuk mendapatkan informasi secara tertulis atau lisan tentang kebijakan penanggulangan bencana dan berkewajiban untuk memberikan informasi yang benar kepada publik tentang penanggulangan bencana. Informasi menjadi hal yang mendasar bagi pelaksanaan pengurangan risiko bencana.

Pentingnya informasi juga ditekankan pada kajian komunikasi lingkungan untuk membuat strategi komunikasi yang efektif guna mengubah perilaku masyarakat korban bencana. Penggunaan pendekatan sains untuk kepentingan bencanaalam dijaman informasi dan teknologi yang telah berkembang pesat menjadikan akses informasi sebagai media yang tepat digunakan meskipun seringkali terjadi konflik antara pelaksanaan kebijakan pemerintah yang menggunakan pendekatan sains dengan masyarakat lokal yang menggunakan pendekatan kultural. Dalam hal ini masyarakat sering dihadapkan dengan pilihan berbagai informasi terkait bencana karena ternyata terdapat juga korelasi positif antara besarnya penduduk yang masih memercayai mitos dengan jumlah frekuensi penyuluhan yang diberikan (Lestari, 2016: 4269; Kusumaningtyas, 2007: 14, Setyarto, 2012; Miswanta, 2009).

Terkait informasi tradisional tentang bencana maka uraian Effendi (2011: 84-85) dan Surono dalam Nugroho,dkk (2016: xv) dapat digunakan untuk menjelaskan bahwa dalam pandangan masyarakat awam, peristiwa bencana alam mengilhami praktikpraktik diluar ilmu, yaitu secara akal sehat (common sense) dan spiritual. Sikap berempati dan memberi respek kepada keseluruhan konteks cara hidup masyarakat sangatlah diperlukan, termasuk bila pada masyarakat tersebut memiliki cara hidup yang dianggap menyalahi akal sehat atau tidak masuk akal 
bagi orang luar, tidak perlu dilihat sebagai penghalang, melainkan bisa justru sangat berguna dalam bencana. Pendapat Abdullah tentang hal ini adalah karena masyarakat lokal yang menganggap bahwa setiap persitiwa bencana alam adalah kehendak Sang Pencipta dan karena mereka belum menggunakan tekonologi maka hal ini lebih mengarah kepada gambaran pendekatan behavioristik, yang hanya menitikberatkan bentuk respon individu terhadap bencanaalam (Effendi, 2007: 77).

Nugroho dkk (2016: 36-37) menemukan pandangan tentang komunikasi masyarakat dalam memaknai bencana gunung Kelud Jawa Timur yang telah memadukan pemahaman antara saintifik dengan pengetahuan lokal yang berakar pada pemahaman kejawaan yang berorientasi keharmonisan dan keselarasan.

Informasi yang digunakan masyarakat dalam peristiwa bencana seringkali berbeda meskipun berada pada wilayah yang sama, misalnya perbedaan respon masyarakat yang berbeda ras pada peristiwa badai Katrina di Amerika, sehingga perlu dilakukan pengolahan pesan yang lebih baik untuk mendukung masyarakat dalam situasi krisis. Perbedaan ini dikarenakan setiap individu lebih menaruh perhatian pada pesan-pesan yang lebih terpapar sebelumnya dan mengitegrasikan dengan pengetahuan yang dimiliki sehingga pengetahuan yang baru dapat mengubah sikapnya (Spance dkk, 2007; Coppola dan Maloney, 2009: 6).

Salah satu upaya pengurangan risiko bencana adalah dengan tindakan penyebarluasan informasi yang terus menerus guna mengurangi risiko bencana, sehingga fenomena alam disetiap wilayah yang memiliki potensi bencana harus difokuskan pada tindakantindakan tertentu agar bahaya peristiwa alam tidak berkembang menjadi sebuah bencana.

Penelitian ini dilakukan di dusun Kalitengahkidul Sleman Jawa Tengah yang termasuk terparah saat dilanda erupsi besar gunung Merapi tahun 2010. Warga harus waspada karena Merapi adalah gunung berapi teraktif di dunia yang bisa mengalami erupsi kapanpun. Wilayah ini terletak tiga kilometer dari puncak Merapi dan pada erupsi 2010 merupakan wilayah terparah dilanda bencana. Aset yang dimiliki warga seperti rumah dan ternak hampir tidak tersisa dan membutuhkan waktu bertahun-tahun lebih bagi warga untuk mengembalikan kondisinya. Pasca erupsi wilayah ini telah ditetapkan oleh pemerintah sebagai zona merah yang tidak boleh ditempati, namun karena alasan mata pencarian dan sejarah maka warga kembali menempatinya.

Upaya yang memadai untuk mengurangi risiko bencana alam banjir di Jawa Timur dari kajian Ulum (2013: 11) menekankan tentang manajemen bencana tidak hanya menuntut partisipasi individu dalam komunitas yang rentan, tetapi juga keterlibatan instansi pemerintah terkait, lembaga swadaya masyarakat dan sektor swasta. Maka dalam hal kapasitas penyebarluasan informasi untuk pengurangan risiko bencana dari pihak-pihak tersebut amat penting perannya. Peneliti menganggap bahwa kajian mengenai informasi tentang bencana alam yang selama ini dibutuhkan masyarakat untuk pengurangan risiko bencana perlu dikaji lebih dalam.

Pengertian tentang informasi yang dikemukakan oleh Shanon (Ritchie, 1991: 6-8) memandang informasi dari terminologi mekanik. 
Komunikasi antar manusia memiliki elemenelemen seperti sinyal, transmisi, encoding dan decoding. Sementara Weavermengembangkan konsep tersebut dengan menekankan bahwa perlu ditambahkan elemen mengenai arti dari informasi dan bagaimana informasi dapat berjalan dengan efektif. Sehingga komunikasi bukan hanya sekedar transmisi secara fisik.

Konsep lain tentang informasi menyebutkan bahwa informasi dapat dianggap sebagai sejumlah pilihan atau alternatif yang digunakan untuk memprediksi suatu hasil. Pada situasi yang kompleks dengan berbagai macam kemungkinan hasil, informasi lebih banyak tersedia dibandingkan dengan pada situasi yang sederhana dan dengan kemungkinan hasil yang lebih sedikit. Semakin banyak informasi yang dimiliki, maka kemungkinan alternatif yang diperoleh akan semakin banyak (LittleJohn \& Foss,2008:42). Konsep transmisi informasi yang digunakan pada penelitian ini bukan memberikan fokus pada arti sebuah informasi namun terfokus pada bagaimana informasi dipindahkan dan diterima, dan selanjutnya informasi akan membantu dalam mengurangi ketidakpastian. Situasi yang kompleks juga dapat disamakan dengan situasi pada saat terjadi bencana alam. Pada kondisi tanggap darurat bencana bahkan pada fase pasca bencana dibutuhkan berbagai informasi untuk memenuhi kebutuhan korban bencana. Pihak yang memberikan bantuan juga memerlukan informasi untuk menyalurkan berbagai jenis bantuan baik fisik maupun psikologis.

Elemen fundamental dalam konsep komunikasi selain konsep jaringan adalah konvergensi yang merupakan unsur yang dapat menghasilkan informasi yang demikian pentingnya informasi karena terdapat perbedaan yang signifikan ketika harus menentukan pilihan dari beberapa alternatif yang ada. Sehingga dalam penjelasan yang lebih luas dengan informasi maka dapat mengurangi ketidakpastian (Rogers dan Kincaid,1981: 48; Pearson \& Nelson dalam Ritchie, 1991: 3).

Proses pengaliran informasi dalam konteks peristiwa bencana juga ditemukan dalam suatu kajian tentang modal sosial dalam jaringan komunikasi masyarakat di Merapi. Modal sosial berperan dalam memfasilitasi aliran informasi tentang kesiapsiagaan menghadapi bencana dari berbagai aliran resmi kepada warga lokal (Wardyaningrum, 2016: 53).

Salah satu bagian terpenting tentang konsep informasi adalah bagaimana informasi dapat menentukan perubahan dalam masyarakat. Penelitian Evert M Rogers dan Johanes van Es dalam Rogers (1995: 89) menemukan bahwa kegagalan atau suksesnya suatu program difusi tergantung dari peran opinion leader dan hubungan mereka dengan para agen perubahan dalam menyebarkan informasi baru. Orang-orang yang menjadi opinion leader pada umumnya memiliki karakter seperti memiliki pendidikan formal, tingkat kecerdasan yang lebih tinggi, lebih besar daya inovasinya, lebih tinggi status ekonominya dan lebih terekspos oleh media.

Akses seseorang terhadap informasi tersebut relevan dengan uraian Dahlan (1979: 2) mengenai pentingnya pemerataan informasi. Bahwa akses terhadap informasi cenderung hanya diperoleh pada kelompok masyarakat tertentu. Informasi dapat lebih mudah diperoleh pada golongan masyarakat 
yang tingkat ekonominya lebih tinggi dan mampu menguasai informasi. Masyarakat yang miskin secara struktural juga akan mengalami kemiskinan informasi. Informasi yang diperoleh umumnya hanya yang bersifat umum, sudah terlambat, kurang bernilai atau tidak relevan lagi baginya. Berdasarkan hal tersebut maka faktor kemiskinan struktural menentukan peluang sebagian masyarakat dalam memperoleh akses informasi. Kesempatan untuk memperoleh peluang pekerjaan, pendidikan, usaha dan sebagainya tidak secara merata diperoleh masyarakat karena akses informasi yang tidak merata.

Hipotesa pertama yang terbangun berdasar uraian tersebut adalah bahwa pendidikan warga menentukan pilihan kepercayaannya terhadap informasi tradisional atau informasi modern tentang bencana.

Pada penelitian Evert M Rogers dan Johanes van Es ditemukan bahwa pada desa yang modern orang-orang yang menjadi opinion leader merupakan orang-orang muda yang inovatif, yang merefleksikan norma dan sistem yang ada. Wilayah yang menganut sistem tradisional para pemimpinnya berusia tua dan kurang inovatif. Hipotesa kedua yang terbangun adalah perbedaan usia warga akan menentukan pilihan kepercayaannya terhadap informasi tradisional atau informasi modern tentang bencana.

Konsep opinion leader ini juga sejalan dengan uraian Rubben dan Stewart yang membahas tentang sumber asal informasi. Orang tentu mempertimbangkan siapa yang menjadi rujukan untuk memperoleh informasi terlebih dalam situasi yang kompleks seperti pada saat terjadi bencana. Konsep informasi juga membahas sumber informasi dimana dalam konsep source influences dalam Rubben dan Stewart (2006: 112) menjelaskan mengapa kita lebih mendengarkan dan percaya pada seseorang atau sebagian orang dibandingkan pada seseorang atau sebagian orang lainnya, atau mengapa kita dapat dipengaruhi oleh orang tertentu dibandingkan yang lain. Adapun faktor-faktor yang mempengaruhi adalah kedekatan (proximity), kesamaan (similiarity), kepercayaan terhadap orang tersebut (credibility), adanya otoritas tertentu yang dimiliki oleh orang tersebut (autoritativenes), adanya motivasi tertentu terhadap seseorang (motivation), kekerapan hubungan aatau pertemuan (intensity), bagaimana pesan disampaikan oleh sumber pesan (delivery), pesan biasanya lebih diterima ketika disampaikan oleh orang-orang yang memiliki status, kekuasaan atau otoritas tertentu (status, power and authority).

Dikarenakan wilayah penelitian ini terdapat warga yang memiliki peran sebagai pemuka agama, kepala dusun dan sebagainya, maka peneliti mengasumsikan mereka juga dapat disebut mereka sebagai opinion leader. Hipotesa ketiga yang terbangun adalah bahwa peran warga di masyarakat menentukan kepercayaan mereka terhadap informasi tradisional atau informasi modern tentang bencana.

Penelitian ini bertujuan; 1) mengidentifikasi adanya hubungan antara perbedaan tingkat pendidikan warga dengan pilihan jenis informasi tradisional atau informasi modern tentang bencana alam. 2) mengidentifikasi adanya hubungan antara perbedaan usia warga dengan pilihan jenis informasi 
tradisional atau informasi modern tentang bencana alam. 3) mengidentifikasi adanya hubungan antara perbedaan peran warga dengan pilihan jenis informasi tradisional atau informasi modern tentang bencana alam. Tinjauan dari tiga komponen yaitu tingkat pendidikan, usia, dan peran warga dalam menentukan pilihan informasi antara informasi tradisional dan informasi modern merupakan kebaruan penelitian tentang komunikasi bencana.

Berdasarkan latar belakang yang sudah dipaparkan, maka tujuan dari penelitian ini adalah untuk mengidentifikasi kepercayaan warga lokal terhadap informasi tradisional dan informasi modern tentang peristiwa bencana erupsi gunung Merapi di Jawa Tengah sebagai salah satu gunung berapi teraktif didunia.

\section{Metode Penelitian}

Penelitian ini menggunakan paradigma post positivist. Pengumpulan data dilakukan melaluisurveypadapopulasiwargadusununtuk memperoleh data kuantitatif tentang demografi responden yang meliputi pendidikan, usia serta peran warga dimasyarakat. Warga dusun yang dipilih sebagai responden adalah mereka yang telah berusia 17 saat terjadi erupsi besar tahun 2010 karena hal tersebut merupakan peritiwa yang meninggalkan trauma maka warga mudah digali kembali ingatannya. Jenis pertanyaan survey tentang pilihan informasi tradisional adalah terkait kepercayaan, mitos, dan kisahkisah yang terkait dengan bencana alam yang telah dipercaya secara turun temurun.

Informasi modern antara lain seputar tanda-tanda terjadinya erupsi berdasarkan pengetahuan modern diidentifikasi menggunakan alat pemantau seperti seismograph dan sebagainya. Informasi modern diperoleh dari instansi resmi seperti perangkat dusun dan pemerintah kabupaten serta relawan bencana. Hasil data survey selanjutnya didukung dengan wawancara dengan warga lokal, perangkat dusun serta relawan bencana. Peneliti juga melakukan pengamatan di lapangan untuk mengonfirmasi hasil survey dan wawancara.

\section{Hasil Penelitian dan Pembahasan}

Penelitian ini merupakan pengembangan dari penelitian pendahulu tentang struktur jaringan komunikasi mitigasi bencana (Wardyaningrum, 2016) yang salah satu temuannya adalah adanya aktor-aktor yang menggunakan informasi yang berbeda pada setiap fase mitigasi bencana.

Hubungan antara perbedaan pada tingkat pendidikan warga (pendidikan dasar, pendidikan menengah maupun pendidikan tinggi) memiliki korelasi dengan jenis informasi tentang bencana yang dipilih. Jumlah warga yang percaya informasi tradisional lebih banyak dibandingkan dengan warga yang memilih informasi modern pada berbagai tingkat pendidikan. Artinya masih lebih banyak warga yang memercayai informasi bencana berdasarkan mitos, cerita, atau mimpi tentang terjadinya erupsi Merapi yang dimaknai sebagai bencana alam.

Warga yang memercayai informasi tradisional sebagian besar tingkat pendidikannya berada pada tingkat Sekolah Dasar. Kondisi ini dapat dipahami bahwa dengan tingkat pendidikan warga yang berada tingkat pada Sekolah Dasar maka akses terhadap informasi modern masih sangat kurang. Sikap warga yang umumnya belum menganggap penting pendidikan serta 
Tabel 1. Perhitungan data pendidikan penduduk

informasi * Pendidikan Crosstabulation

\begin{tabular}{|c|c|c|c|c|c|c|}
\hline & & & \multicolumn{3}{|c|}{ Pendidikan } & \multirow[t]{2}{*}{ Total } \\
\hline & & & Dasar & Menengah & Tinggi & \\
\hline \multirow{4}{*}{ informasi } & \multirow{2}{*}{ Tradisional } & Count & 85 & 12 & 10 & 107 \\
\hline & & $\%$ within informasi & $79.4 \%$ & $11.2 \%$ & $9.3 \%$ & $100.0 \%$ \\
\hline & \multirow{2}{*}{ Modern } & Count & 51 & 9 & 9 & 69 \\
\hline & & $\%$ within information & $73.9 \%$ & $13.0 \%$ & $13.0 \%$ & $100.0 \%$ \\
\hline \multirow{2}{*}{ Total } & & Count & 136 & 21 & 19 & 176 \\
\hline & & $\%$ of information & $77.3 \%$ & $11.9 \%$ & $10.8 \%$ & $100.0 \%$ \\
\hline \multicolumn{7}{|c|}{ Chi-Square Tests } \\
\hline & & & Value & $\mathrm{df}$ & \multicolumn{2}{|c|}{ Asymp. Sig. (2-sided) } \\
\hline \multicolumn{3}{|c|}{ Pearson Chi-Square } & $.815^{\mathrm{a}}$ & 2 & & .665 \\
\hline \multicolumn{3}{|c|}{ Likelihood Ratio } & .804 & 2 & & .669 \\
\hline \multicolumn{3}{|c|}{ Linear-by-Linear Association } & .809 & 1 & & .368 \\
\hline \multicolumn{3}{|c|}{$\mathrm{N}$ of Valid Cases } & 176 & & & \\
\hline
\end{tabular}

a. 0 cells $(.0 \%)$ have expected count less than 5 . The minimum expected count is 7.45 .

Sumber : Data Peneliti 2017

dengan mata pencarian warga yang bertani dan berternak maka cukup untuk memperoleh penghasilan dengan menggunakan ketrampilan yang merupakan bagian dari kearifan lokal yang diperoleh secara turun temurun. Selain itu warga umumnya hanya berinteraksi dengan orang-orang disekitarnya yang masih banyak memercayai informasi tradisional juga. Edukasi tentang mitigasi bencana dari pihak luar seperti pemerintah daerah sebagaimana pendapat Ulum tentang pentingnya keterlibatan berbagai pihak tentang pemahaman bencana secara modern belum secara rutin disampaikan kepada warga lokal.

Relevan dengan temuan Rogers dkk serta Dahlan bahwa akses informasi hanya diperolehpadakelompokmasyarakattertentu yang antara lain karena tingkat ekonomi dan pendidikan lebih tinggi sehingga mampu menguasai informasi. Informasi yang diperoleh masyarakat miskin umumnya hanya informasi yang bersifat umum, sudah terlambat, kurang bernilai atau tidak relevan lagi baginya atau akses informasi tidak merata. Kehadiran opinion leader yang dapat memberikan informasi baru juga nampak kurang di wilayah ini karena masyarakat umumnya hanya mendapatkan informasi tentang bencana tidak secara rutin dan terprogram. Padahal wilayah ini cukup dekat dengan ibukota propinsi dan daerah Istimewa Yogyakarta dimana banyak kalangan masyarakat dari pendidikan tinggi maupun pemerintah. Kedua unsur tersebut seperti yang dikemukakan oleh Rubben dan Stewart dapat menjadi opinion leader yang dapat dan mempengaruhi masyarakat karena faktor-faktor adanya unsur kepercayaan (credibility) dan adanya otoritas tertentu yang dimiliki (autoritativenes). Informasi yang diperoleh tentunya dapat menjadi 
pilihan informasi bagi masyarakat untuk mengambil keputusan.

Hasil perhitungan korelasi dengan nilai 0.815 menunjukkan adanya pengaruh antara perbedaan tingkat pendidikan dengan pilihan jenis informasi, namun dengan angka hasil signifikansi 0.665 maka pengaruh tersebut tidak signifikan. Dapat diartikan bahwa perbedaan tingkat pendidikan warga tidak memengaruhi secara signifikan terhadap pilihan kepercayaan warga terhadap informasi tradisional atau informasi modern tentang bencana erupsi.

Korelasi antara perbedaan usia warga dengan kepercayaan terhadap informasi tradisional dan informasi modern tentang bencana

Pada masing-masing kelompok usia (muda, dewasa dan tua) ditemukan jumlah warga yang memilih informasi tradisional lebih banyak dibandingkan warga yang memilih informasi modern. 42.1\% (107 orang) memilih informasi tradisional dan 36.2\% (69 orang) memilih informasi modern.Warga lokal yang memercayai informasi tradisional lebih banyak warga yang berusia tua, sementara warga yang memercayai informasi modern adalah warga yang berusia muda. Hal ini dapat dinalisa bahwa pada warga yang berusia muda nampak sudah lebih terbuka terhadap pihak luar seperti interaksi dengan para relawan dan umumnya sudah menggunakan teknologi komunikasi. Perilaku ini memberikan peluang bagi warga usia muda untuk memperoleh informasi modern meskipun lingkungannya masih dilingkupi budaya lokal yang memercayai informasi tradisional dan disampaikan turun-temurun.

Kepercayaan warga terhadap informasi tradisional umumnya masih dipercaya oleh warga berusia tua tidak menimbulkan konflik denganwargausiamudayanglebihmemercayai informasi modern. Hal ini Salah satu bentuk kepercayaan warga di dusun Kalitengahkidul adalah dengan melanggengkan tradisi upacara ritual labuhan Merapi rutin setiap tahun yang diikuti oleh kaum pria dari orang tua hingga pemuda bahkan anak-anak. Bagi orangorang muda meskipun sebagian besar telah banyak menerima informasi modern tentang bencana namun mereka masih menghormati kepercayaan tradisional yang dipercaya warga usia tua.

Temuan bahwa warga yang berusia tua lebih percaya pada informasi tradisional relevan dengan kajian Rogers dan Dahlan yang menemukan bahwa pada desa yang modern orang-orang yang menjadi opinion leader merupakan orang-orang muda yang inovatif, yang merefleksikan norma dan sistem yang ada. Sementara pada wilayah yang menganut sistem yang tradisional para pemimpinnya berusia tua dan kurang inovatif. Perbedaan pilihan informasi warga di wilayah ini tidak menimbulkan konflik seperti yang ditemukan pada beberapa kajian Setyarto tentang respon masyarakat saat bencana diwilayah lain. Adanya perbedaan respon tentang bencana ini dapat dipahami dari konsep yang dikemukakan Coppola dan Maloney bahwa adanya perbedaan kelompok masyarakat yang merespon bencana timbul berdasarkan informasi yang diperoleh atau dipercayainya adalah karena setiap individu cenderung lebih menaruh perhatian pada pesan-pesan yang mereka sudah terpapar sebelumnya dan menggunakan pengalaman masa lalunya untuk mengevaluasi informasi yang diperoleh. 
Tabel 2. Data usia warga

informasi * Usia Crosstabulation

\begin{tabular}{|c|c|c|c|c|c|c|c|}
\hline & & & & \multicolumn{3}{|c|}{ Usia } & \multirow[t]{2}{*}{ Total } \\
\hline & & & & muda & dewasa & tua & \\
\hline \multirow[t]{4}{*}{ informasi } & \multirow{2}{*}{ Tradisional } & \multicolumn{2}{|l|}{ Count } & 38 & 24 & 45 & 107 \\
\hline & & \multicolumn{2}{|c|}{$\%$ of information } & $35.5 \%$ & $22.4 \%$ & $42.1 \%$ & $100.0 \%$ \\
\hline & \multirow{2}{*}{ Modern } & Count & & 27 & 17 & 25 & 69 \\
\hline & & $\%$ withi & ormation & $39.1 \%$ & $24.6 \%$ & $36.2 \%$ & $100.0 \%$ \\
\hline \multirow{3}{*}{\multicolumn{2}{|c|}{ Total }} & Count & & 65 & 41 & 70 & 176 \\
\hline & & $\%$ withi & ormation & $36.9 \%$ & $23.3 \%$ & $39.8 \%$ & $100.0 \%$ \\
\hline & & Value & Df & \multicolumn{4}{|c|}{ Asymp. Sig. (2-sided) } \\
\hline \multicolumn{2}{|c|}{ Pearson Chi-Square } & $.594^{\mathrm{a}}$ & 2 & & & & .743 \\
\hline \multicolumn{2}{|c|}{ Likelihood Ratio } & .597 & 2 & & & & .742 \\
\hline \multicolumn{2}{|c|}{ Linear-by-Linear Association } & .485 & 1 & & & & .486 \\
\hline \multicolumn{2}{|c|}{$\mathrm{N}$ of Valid Cases } & 176 & & & & & \\
\hline
\end{tabular}

a. 0 cells $(.0 \%)$ have expected count less than 5 . The minimum expected count is 16.07 .

Nilai 0.594 menjelaskan hubungan antara perbedaan usia warga dengan pilihan jenis informasi namun dari perhitungan signifikansi sebesar 0.743 maka hubungan tersebut tidak cukup signifikan, atau dengan kata lain perbedaan usia warga tidak menentukan perbedaan pilihan warga terhadap informasi tradisional atau informasi modern tentang bencana. Perbedaan yang tidak signifikan ini disatu sisi sebagai bisa menjadi peluang untuk mensinergikan antara informasi tradisional dan modern tentang bencana kepada masyarakat.

\section{Korelasi antara perbedaan peran warga di masyarakat dengan pilihan jenis informasi tradisional dan informasi modern tentang bencana}

Pada variabel peran warga dimasyarakat diperoleh perhitungan pada masing-masing jenis peran warga (sebagai anggota PKK, relawan, ustad, ketua RT dan RW, dan warga yang tidak memiliki peran) lebih banyak warga yang memilih informasi tradisional (107 orang) dibandingkan yang memilih informasi modern (69 orang). Warga yang memilih informasi tradisional sebagian besar tidak memiliki peran di masyarakat. Kecenderungan pilihan pada informasi tradisional ini dapat dipahami karena kelompok warga ini kurang berinteraksi dengan pihak lain terutama orangorang dari luar dusun seperti pemerintah daerah atau relawan bencana yang menggunakan informasi modern. Pada kelompok warga yang percaya terhadap informasi modern meskipun jumlahnya lebih banyak pada warga yang tidak memiliki perankemungkinan adalah warga usia muda yang sudah lebih terbuka dan berinteraksi dengan orang-orang dari wilayah lain serta menggunakan teknologi komunikasi. Disisi lain banyak ditemukan kelompok warga yang merupakan anggota PKK karena dari organisasi PKK terdapat peluang masuknya informasi modern seperti tentang ketrampilan, kesehatan dan mitigasi bencana bagi anggota keluarga.

Gambaran warga tersebut juga dapat diperoleh dari penjelasan Oktarina dkk dalam 
kajiannya tentang informasi kesehatan bagi warga di daerah rawan bencana gunung berapi yang telah mengalami perubahan tentang informasi terkait peristiwa bencana. Hasil temuannya menunjukkan bahwa kesadaran warga tentang kesehatan umumnya masih rendah dan program tentang kesehatan yang ada selama ini dilakukan dengan pendekatan yang bersifat tradisional. Disisi lain, terdapat warga yang menginginkan informasi tentang cara menghadapi bencana disampaikan dengan menggunakan media audio visual. Informasi yang dibutuhkan warga adalah hal-hal yang terkait dengan dampak letusan terhadap kesehatan warga dalam jangka panjang. Dengan peran-peran yang dimiliki warga ditengah masyarakat membuat warga lebih terbuka relasi komunikasinya dengan pihak lain sehingga dapat meningkatkan pengetahuan, wawasan dan menerima berbagai alternatif informasi.

Melalui peran warga dimasyarakat maka dapat digunakan pendekatan kognitif untuk mengubah sikap warga terhadap informasi, karena menurut Leandre dkk dalam LittleJohn \& Foss diuraikan bahwa pendekatan kognitif menggambarkan sebuah sistem tentang adanya interaksi diantara informasi yang diperoleh. Hal tersebut kemudian dapat mendorong dan memberikan pengaruh terhadap kepercayaan seseorang atau perilakunya. Sikap seseorang akan terbentuk karena akumulasi informasi yang diperoleh tentang suatu objek, orang, situasi dan pengalaman. Pengalaman seseorang dalam menjalankan perannya dalam masyarakat lebih memberikan peluang adanya akumulasi berbagai informasi dari interaksinya dengan banyak pihak serta dari situasi dan pengalaman yang diperoleh.

Tabel 3. Peran masyarakat pada lingkungan

informasi * Peran di Masyarakat Crosstabulation

\begin{tabular}{|c|c|c|c|c|c|c|c|c|}
\hline & & & \multicolumn{5}{|c|}{ Peran di Masyarakat } & \multirow[t]{2}{*}{ Total } \\
\hline & & & $\begin{array}{l}\text { tidak } \\
\text { ada }\end{array}$ & $\begin{array}{l}\text { Anggota } \\
\text { PKK }\end{array}$ & Relawan & Ustad & $\mathrm{Rt} / \mathrm{RW}$ & \\
\hline \multirow{4}{*}{ Informasi } & \multirow{3}{*}{ Tradisional } & Count & 57 & 26 & 14 & 5 & 5 & 107 \\
\hline & & $\begin{array}{l}\text { \% within } \\
\text { informasi }\end{array}$ & $53.3 \%$ & $24.3 \%$ & $13.1 \%$ & $4.7 \%$ & $4.7 \%$ & $100.0 \%$ \\
\hline & & Count & 34 & 27 & 5 & 0 & 3 & 69 \\
\hline & \multirow[t]{3}{*}{ modern } & $\begin{array}{l}\% \text { within } \\
\text { information }\end{array}$ & $49.3 \%$ & $39.1 \%$ & $7.2 \%$ & $0.0 \%$ & $4.3 \%$ & $100.0 \%$ \\
\hline \multirow[t]{2}{*}{ Total } & & Count & 91 & 53 & 19 & 5 & 8 & 176 \\
\hline & & $\begin{array}{l}\% \text { within } \\
\text { information }\end{array}$ & $51.7 \%$ & $30.1 \%$ & $10.8 \%$ & $2.8 \%$ & $4.5 \%$ & $100.0 \%$ \\
\hline \multicolumn{9}{|c|}{ Chi-Square Tests } \\
\hline & & & & \multicolumn{2}{|c|}{ Value } & $\mathrm{df}$ & \multicolumn{2}{|c|}{ Asymp. Sig. (2-sided) } \\
\hline \multicolumn{3}{|c|}{ Pearson Chi-Square } & & \multicolumn{2}{|c|}{$7.752^{\mathrm{a}}$} & 4 & & .101 \\
\hline \multicolumn{3}{|c|}{ Likelihood Ratio } & & \multicolumn{2}{|c|}{9.502} & 4 & & .050 \\
\hline \multicolumn{3}{|c|}{ Linear-by-Linear Association } & & \multicolumn{2}{|c|}{.774} & 1 & & .379 \\
\hline \multicolumn{3}{|c|}{$\mathrm{N}$ of Valid Cases } & & \multicolumn{2}{|r|}{176} & & & \\
\hline
\end{tabular}

a. 4 cells $(40.0 \%)$ have expected count less than 5 . The minimum expected count is 1.96 .

Sumber: Data Peneliti 2017 
Perhitungan nilai korelasi menghasilkan angka 7.752 sehingga terdapat korelasi yang sangat kuat, namun dengan hasil asymp. sig sebesar 0.101 yang nilainya lebih besar dari 0.05 maka nilai korelasinyatidak cukup signifikan. Dapat disimpulkan bahwa perbedaan peran warga di masyarakat tidak menentukan perbedaan kepercayaan mereka terhadap jenis informasi tradisional maupun informasi modern tentang bencana.

Warga dusun masih lebih banyak mengandalkan informasi tradisional tentang risiko bencana erupsi karena adanya kedekatan dengan anggota keluarga seperti para sesepuhatau orang-orang tua yang dianggap memiliki pengalaman panjang tentang erupsi. Informasi tradisional yang dipercaya warga mencakup mitos, kisahkisah tokoh sejarah atau tokoh dalam pewayangan Jawa dan mimpi yang dialami menjelang terjadinya bencana. Informasi tradisionl ini disampaikan oleh warga secara turun termurun. Kisah tentang tokoh-tokoh pewayangan dianggap sebagai makhluk penghuni gunung yang pada waktu waktu tertentu perlu dilakukan aktivitas ritual, dan tokoh pewayangan dianggap mewakili dewa yang memberikanpertanda akan terjadinya musibah.

Warga lebih menaruh kepercayaan sumber informasi tradisional yang diperoleh dari orang-orang disekitar mereka yang dianggap memiliki kedekatan (proximity) dan memiliki kesamaan pengalaman (similiarity) serta kekerapan pertemuan (intensity) yang dialami setiap hari.Unsur kedekatan (proximity) adalah karena warga umumnya tinggal berdekatan dan memiliki hubungan keluarga dengan warga lainnya yang diantaranya terdiri dari orang-orag tua yang menjadi saksi hidup dalam peristiwa erupsi erupsi sebelumnya. Unsur kesamaan pengalaman (similiarity) adalah ketika orang-orang yang tinggal diwilayah yang sama mengalami pengalaman yang sama dalam menghadapi ancaman bencana erupsi. Kekerapan pertemuan (intensity) yang dialami setiap hari juga terjadi pada warga dusun yang bukan saja tinggal berdekatan dalam satu wilayah, namun memiliki jenis pekerjaan yang sama yaitu bertani, beternak dan menggali pasir sehingga memiliki intensitas pertemuan yang tinggi.

Adapun informasi tradisional biasanya disampaikan oleh sumber pesan (delivery) secara turun temurun melalui dongeng tentang mitos, hal-hal yang bersifat tersirat seperti mimpi dan peristiwa tertentu yang dianggap sebagai pertanda akan terjadi bencana atau tidak terjadi bencana.

Jenis informasi tradisional yang dipercaya oleh warga antara lain adalah seperti mitos berupa kisah-kisah yang disampaikan oleh nenek moyang mereka bahwa erupsi tidak akan mengarah ke dusun mereka karena warga melihat awan berbentuk tokoh pewayangan petruk yang kepalanya mengarah ke wilayah lain. Warga masih percaya bahwa erupsi Merapi hanya sementara karena berdasarkan pengalaman masa lalu dan kepercayaan dari para orangorang tua bahwa merapi sangat baik dan hanya "batuk-batuk" sehingga tidak akan menimbulkan bencana besar.

Di sisi lain pesan atau informasi modern tentang mitigasi bencana sudah 
banyak disampaikan oleh orang-orang yang memiliki status, kekuasaan atau otoritas tertentu (status, power and authority) dalam hal ini adalah kepala dusun, lurah, pemerintah kabupaten bahkan perintah untuk mengungsi sebelum erupsi puncak juga disampaikan dari sultan sebagai gubernur Daerah Istimewa Yogyakarta. Informasi modern adalah informasi yang didasarkan ilmu pengetahuan, disampaikan dari pihak yang berwenang seperti pemerintah kabupaten dan pemerintah daerah setempat, relawan bencana dan melalui media massa.

Lurah bahkan sebagai salah satu warga dusun yang tergolong berusia muda (awal 40 tahun) juga mengakui lebih mempercayai informasi modern yang disampaikan oleh pemerintah kabupaten namun demi menghormati orang-orang generasi tua maka ia turut mempercayai informasi tradisional. Informasi yang disampaikan oleh pemerintah kabupaten dengan menggunakan metode saintifik seperti pengamatan aktivitas gunung yang bukan hanya mengandalkan visual (melihat kepulan asap, arah abu vulkanik dan sebagainya), namun menggunakan alat-alat yang dapat menunjukkan perhitungan aktifitas vulkanik secara lebih akurat. Getaran, suara, dan arah semburan awan dapat dipantau dan diperkirakan intensitasnya dengan menggunakan alat. Hasil pengamatan dan perhitungan saintifik ini dijadikan acuan untuk menjauh dari puncak gunung, atau melakukan evakuasi. Keputusan ini diambil berdasarkan komando dari kepala dusun dan bukan merupakan keputusan yang mudah karena menimbulkan akan menimbulkan berbagai konsekuensi.

Warga berusia muda yang sebagian diantaranya mempercayai informasi modern cenderung tidak mempertentangkan perbedaan kepercayaannya dengan warga generasi tua yang lebih mempercayai informasi tradisional. Temuan ini juga sejalan dengan konsep yang mengemukakan bahwa setiap individu cenderung lebih menaruh perhatian pada pesan-pesan yang mereka sudah sering diterima sebelumnya. Akumulasi informasi tradisional yang diperoleh dari anggota keluarga terdekat tentang erupsi kecil Merapi selama bertahun tahun, tentang pengalaman orang-orang dan situasi yang pernah dialami juga berkontribusi terhadap terbentuknya sikap warga.

Penyebaran informasi yang optimal diperlukan peran opinion leader yang lebih banyak dan lebih mampu menularkan informasi kepada masyarakat. Opinion leader dalam penularan informasi merupakan salah satu elemen dalam proses integrasi informasi seperti tentang kredibiltas seseorang, maupun posisi opinion leader sebagai pihak yang informasinya dapat menambah keyakinan penerima informasi mengenai sesuatu hal yang telah diketahui sebelumnya.

Peluang untuk mengurangi ketidakpastian pada situasi bencana dapat dilakukan dengan ketersediaan informasi yang memadai terutama dalam peritiwa bencana ketika banyak sumberdaya yang dibutuhkan dalam waktu yang bersamaan dan dalam periode yang tidak pasti. 


\section{Simpulan}

Jumlah warga yang percaya terhadap informasi tradisional lebih banyak dibandingkan dengan warga yang mempercayai informasi modern tentang bencana erupsi Merapi. Kepercayaan terhadap informasi tradisional seperti mitos dan mimpi umumnya masih dianut oleh warga yang berusia tua sementara warga usia muda sebagian masih mempercayai informasi tradisional karena merasa perlu menghormati warga yang lebih tua sehinggadiantara warga tidak ditemukan konflik dengan perbedaan pilihan informasi ini. Kepercayaan warga terhadap informasi tradisional sempat menghalangi proses evakuasi oleh pemerintah pada erupsi 2010 yang seharusnya dapat dilakukan lebih awal saat terjadi erupsi. Kelambatan dalam proses evakuasi menyebabkan kerugian harta benda berupa aset andalan warga dusun seperti ternak.

Perbedaan tingkat pendidikan, perbedaan usia dan perbedaan peran warga di masyarakat ternyata tidak secara signifikan membedakan pilihan kepercayaan warga terhadap informasi tradisional dan informasi modern tentang bencana. Kondisi yang demikian tercipta selain karena warga lebih percaya pada orang-orang yang dekat dengan lingkungannya, pengaruh budaya yang dianut, juga akses terhadap informasi tentang mitigasi bencana yang tidak merata dan literasi tentang bencana yang belum dilakukan secara berkesinambungan.

Perbedaan kepercayaan warga terhadap informasi tradisional dan informasi modern yang tidak signifikan merupakan peluanguntuk mengintegrasikan kedua jenis informasi tersebut untuk pengurangan risiko bencana. Perlu dibangun pemahaman bagi masyarakat lokal bahwadenganmenggunakan informasimodern hal ini juga merupakan cara kita hidup bersama dan menghormati alam, serta memaknainya sehingga masyarakat mampu menghadirkan solusipada saat alam membutuhkan ruang dan waktu untuk aktivitasnya.

\section{Daftar Pustaka}

Coppola, Damon P dan Maloney, Erin K \&. (2009). Communicating Emergency Preparedness: Strategic for Creating a Disaster Resilient. USA: Auerbach Publicationa Taylor \& Francis Group.

Dahlan, MAlwi.(1979). Jaringan Komunikasi Sosial sebagai saluran Pemerataan Informasi. Disampaikan dalam Kongres ke 3 Seminar Ilmiah Nasional Himpunan Indonesia untuk Pengembangan Ilmuilmu Sosial 13-17 november di Malang.

Effendi, Nusyirwan. (2007). Bencana : Pengalaman dan Nilai Budaya Orang Minangkabau, Masyarakat Indonesia. Majalah Ilmu -Ilmu Sosial Indonesia, Jilid 33, Vol 2, ISSN 0125-9989. Jakarta: Lembaga Ilmu Pengetahuan Indonesia.

Littlejohn, Stephen W.\& Foss, Karen A, $9^{\text {th }}$. (2008). Theories of Human Communication. United States of America: Belmot, CA Wadsworth Publishing,

Lestari, Puji; et. all. Environmental Communication Model for Disaster Mitigation of Mount Sinabung Eruption, Karo Regency of North Sumatera, Journal Information, Volume 19, Number 9 (B)pp 4265-4270, ISSN 1343-4500, eISSN 1344-8994, C2016. Tokyo: International Information Institute.

Kusumaningtyas, Purwanti. (2007). Intepretasi Ulang Makna Spiritualitas Bencana Dalam Cerita Rakyat Indonesia. Kajian Politik Lokal, Sosial dan Humaniora. Renai. Tahun VII, No 1 Tahun 2007. 
Miswanta. (2009). Problematika Penentuan Waktu Pengungsian. BPPTK, Pusat Vulkanologi dan Mitigasi Bencana Geologi, Badan Geologi .

Oktarina M, Kartika V, Megatsari H. (2011). Pengembangan Media Komunikasi, Informasi dan Edukasi (KIE) Kesehatan bagi Masyarakat di Daerah Bencana Gunung Berapi. Surabaya: Kementerian Kesehatan RI.

Rogers, Evert M \&Kincaid, D Lawrence. (1981). Communication Networks. New York: Free Press

Rogers, Evert M. (1995). Diffusion of Innovations. New York: Free Press.

Ritchie, L. David, (1991). Communication Concept 2: Information. New Delhi: Sage Publication.

Ruben, Brent. D., Lea P. Stewart. (2006). Communication And Human Behaviour. $5^{\text {th }}$ Edition.United States: Pearson Education.

Nugroho, Sutopo Purwo, Diartoko, Paulus, Sulstyo Robert, Men Yon, Kwan, Aprilidia. (2016). Kelud Tanpa Kemelut, Rekam Jejak Inisiatif dan Kiprah Warga Dalam Tanggap darurat Erupsi Gunung Kelud. Jakarta: Badan Nasional Penanggulangan Bencana.
Spence, Patric R, Lachlan Kenneth A. Lachlan and Griffin Donyale R. Crisis Communication, Race, and Natural Disasters. Journal of Black Studies, Vol. 37, No 4, Katrina: Race, Class, and Poverty (Mar. 2007), pp. 539-554. Published by Sage Publications, Inc.

Setyarto, Dwiatmoho Budi. (2012). Konflik Kebijakan dan Pengetahuan Lokal dalam Pengurangan Risiko Bencana Erupsi Gunung Merapi 2010 di Kinahrejo, Desa Umbulharjo, Kabupaten Sleman DIY. Pasca Sarjana Kebijakan Publik Fakultas Ilmu Sosial dan Ilmu Politik Universitas Gajah Mada Yogyakarta.

Ulum, Mochamad Chaezienul. (2013). Governance Dan Capacity Building Dalam Manajemen Bencana Banjir di Indonesia. Jurnal Penanggulangan Bencana Vol 4 no 2 Tahun 2014. Hal 5-12. ISSN 2087636X. Badan Nasional Penanggulangan Bencana.

Wardyaningrum.(2016). Modal Sosial Inklusif dalam Bencana Jaringan Komunikasi. Jurnal Asosiasi Pendidikan Tinggi Ilmu Komunikasi (ASPIKOM), Volume 3, Nomor 1 Juli 2016 (hal 33-55).

Undang-Undang Republik Indonesia Nomor 24 Tahun 2007 tentang Penanggulangan Bencana. 